\title{
原著
}

\section{ヒト卵巣癌株の in vitro 制癌剤感受性試験に関する研究}

一一特に細胞形態を指標とする基礎的検討を中心に一-

東京慈恵会医科大学産科婦人科
安田 裕昭 允 寺島 芳輝 蜂屋 祥一

佐々木研究所付属杏雲堂病院婦人科
杉下 医 天神 美夫

In vitro 制癌剂感受性試験で細胞形態と薬剤感受性，および制癌剤の細胞回転に与える影響を検 討, 化学療法による細胞死の問題も含め, 臨床応用をはかるべく本研究を行った.

卵巣未分化胚細胞腫由来の細胞株 (JOHYL-1) をヌードマウスに移植, この皮下腫瘍より, Single cell suspension を作製, 5-fluorouracil, Mitomycin C, Vincristine, Carbazil quinone の 4 制癌 剤を高濃度短時間, 低濃度長時間をそれぞれ単独接触させ検討した。

1）位相差顕微鏡所見では, 細胞質内顆粒と細胞質ならびに核の腫大を伴った大小突起細胞の出 現を認めた。

2) Pap. 染色所見では，(1) 細胞質の染色性低下ならびに腫大, 空胞出現, 細胞膜の不明瞭化, （2）核の腫大と空胞出現，クロマチンの粗網状変化，(3) 核小体の腫大，不明膫化をそれぞれ認 めた.

3) Tripan blue による dye exclusion method と, 核長径測定による核腫大を検討した結果で は，核腫大と死細胞率の増加が相関関係にあることから，両者には密接な関連性があることが 示唆された。

4） ICP による核 DNA ヒストグラムの解析では CQ による高度な核腫大化をきたした細胞が 細胞回転の停止を認めた.

以上より核腫大と細胞死は密接な関連があり, 感受性試験のパラメーターとなり得ることが示唆 された.

Key words : Ovarian cancer cell line-Sensitivity test in vitro-Anti cancer drugMorphology

\footnotetext{
A study on sensitivity testing in vitro of human ovarian cancer cell line to anticancer drugs - Fundamental study using the parameter of morphological changes Hiroaki INUI, M.D., Makoto YASUDA, M.D., Yoshiteru TERASHIMA, M.D., Shouichi HACHIYA, M.D.

Dept. of Obst. and Gynec., The Jikei University, School of Medicine

Tadashi SUGISHITA, M.D., Yoshio TENJIN, M.D.

Dept. of Gynec., The Medical Institute of Sasaki Foundation Kyoundo Hosp.

論文別刷請求先 画182 東京都狛江市和泉 106 東京慈恵会 医科大学第 3 病院産婦人科

昭和 57 年 6 月 15 日受付
}

\section{I. 緒言}

近年, 各種制癌剂の開発に伴い, 宿主に対し副作用が 少なく，かつ腫瘍細胞に高い感受性を示す，いわゆる制 癌剤感受性試験が多数試みられている.

in vitro 系における制癌剤と細胞形態の関係を検討し た報告は6,9,10,13), 種々みられるけれども細胞形態そのも のを直接, 指標とした制癌版感受性試験の報告は, ほと んど認められていない，それゆえ，制癌剤による細胞死 
判定の問題も含め, 臨床応用をはかるべく本研究を行っ た、また制癌剤が細胞回転に与える影響は，薬剤の投与 法ならびに投与量を決定する際にきわめて重要であり, この問題解決の一助として Impuls cytophotometer （ICP）により 核 DNA ヒストグラムを作製し検討する とともに細胞形態の変化もあわせて観察した.

\section{II. 研究材料ならびに方法}

われわれが樹立した，いわゆる高度異型性の卵巣未分 化胚細胞腫由来と考えられる細胞株 (JOHYL-1) ${ }^{18)}$ を又 一ドマウス皮下に移植，経代 6 打よび 7 代目の同皮下腫 瘍を使用した。

上記腫瘍を約 $1 \mathrm{~mm}^{3}$ に細断, ディスパーゼにて $\sin$ gle cell suspension（約 $10^{6} / \mathrm{m} l$ ), を作製し，5-fluorouracil ( $5 \mathrm{FU})$, Mitomycin $\mathrm{C}(\mathrm{MC})$, Vincristine (VCR), Carbazilquinone (CQ) の 4 制癌剤につき感受性試験を 試みた，濃度決定には JOHYL-1 株の各種薬剤に対する LD 50 を指標とし, 薬剤濃度 $5 \times 10^{-1} \sim 1 \mu \mathrm{g} / \mathrm{ml}, 30$ 分お よび $5 \times 10^{-2} \sim 10^{-1} \mu \mathrm{g} / \mathrm{ml}, 24$ 時間，それぞれ単独接触 させ, dish と Labtek 上に撒布，合計 72 時間 $10 \%$ 仔牛 血清を含む, Eagle MEM にて静置培養し, 以下に述べ るような各種の検索を行った.

\section{A） 各種制癌剤に対する生残率の測定}

Dish 上の生着細胞を $0.25 \%$ トリプシンにて剝離, 非 生着細胞とともに tripan blue の Dye exclusion method にて生細胞を算定し, 無処置コントロール群に対する比 率で表現した.

\section{B）薬剤接触前後の細胞形態の变化}

Dish 上に生着した培養細胞を位相差顕微鏡 200 倍に て観察, 10 視野につき $1 \mathrm{~mm}^{2}$ あたりの平均細胞数を算 定し, 生残率と同様の比率で表すことにした. また Labtek 上に生着した細胞を $50 \%$ エーテルアルコールにて 固定, Papanicolau 染色, 細胞密度の均一な細胞を中心 に 400 倍の光顕で観察, とくに核長径を Micrometer を用いて測定, 細胞 1,000 個の平均値をもって核腫大の 測定值とした.

\section{C） 薬剤接触前後の細胞回転の解析}

1) Labeling index (LI) および Mitosis index (MI) の検討

前記 4 種の制癌剂を 30 分, 24 時間それぞれ接触させ た後, LI は, ${ }^{3} \mathrm{H}$-thymidine $1 \mu \mathrm{ci} / \mathrm{m} l$ にて 30 分培養し, かつ dipping 法にて処理, Silver grain 30 個以上の細胞 を, MI は核分剖像を示す細胞を対象として,それぞれ細

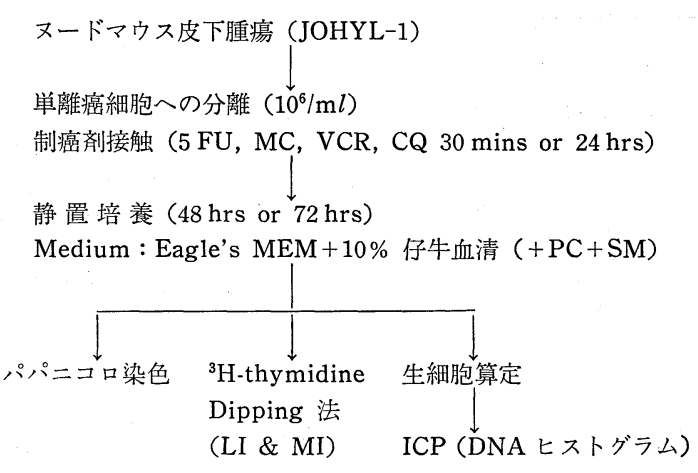

図 1 材料と方法

胞数 1,000 個についての比率を算出した.

2）ICP を用いた核 DNA ヒストグラムの検討

Dish 上の生着および非生着細胞を $0.25 \%$ トリプシン にて剝離し，50\% エタノールにて固定, Pepsin 処理後, Etidium bromide にて螢光染色し ICP 測定に供した (図 1).

\section{III. 研 究 成 績}

A）各種制癌放に対する生残率測定

30 分接触群では $5 \mathrm{FU}\left(5 \times 10^{-1} \mu \mathrm{g} / \mathrm{ml}\right), \mathrm{MC}(1 \mu \mathrm{g} /$ $\mathrm{m} l), \mathrm{VCR}(1 \mu \mathrm{g} / \mathrm{m} l), \mathrm{CQ}(1 \mu \mathrm{g} / \mathrm{m} l)$ の順に生残率は低 下し，とくに殺細胞効果は, $\mathrm{VCR}, \mathrm{CQ}$ で著明であった.

24 時間接触群では，生残率は当然のことながら 30 分 接触群に比し著しく低下した. とくに MC $\left(10^{-1} \mu \mathrm{g} /\right.$ $\mathrm{m} l), \mathrm{CQ}\left(10^{-1} \mu \mathrm{g} / \mathrm{ml}\right)$ は, 殺細胞的に働き, $\mathrm{VCR}$ では 30 分接触とほぼ同值を示した（図 2 ).

B ) 形態学的観察

1) 位相差顕微鏡所見

各種制癌剂を, これまた 30 分, 24 時間，接触させ 検 討した. 無処置コントロール 72 時間培養における 細胞 は, 敷石状に増殖し, 細胞質, 核ともに円形〜楕円形 で，核内に 1 個以上の核小体を認めた（写真 1 ).

$5 \mathrm{FU} 30$ 分接触の位相差顕微鏡における所見では，細 胞密度が対照群に比し約 $40 \%$ 程度，疎となり，細胞質 内は対照群にあまり認めない顆粒が出現し, 細胞質, 核 ともに腫大かつ扁平化を呈した（写真 2 ).

$5 \mathrm{FU} 24$ 時間接触では, 生着しない浮遊細胞が増加し たためか, 細胞密度は対照群に比し約 $10 \%$ と極度に疎 となり，細胞周辺に小突起が出現するとともに細胞質内 顆粒をもった細胞が増加し，核および細胞質の腫大傾向 も著明となった (写真 3 ).

MC 30 分接触では, 細胞密度がこれまた対照群に 比 

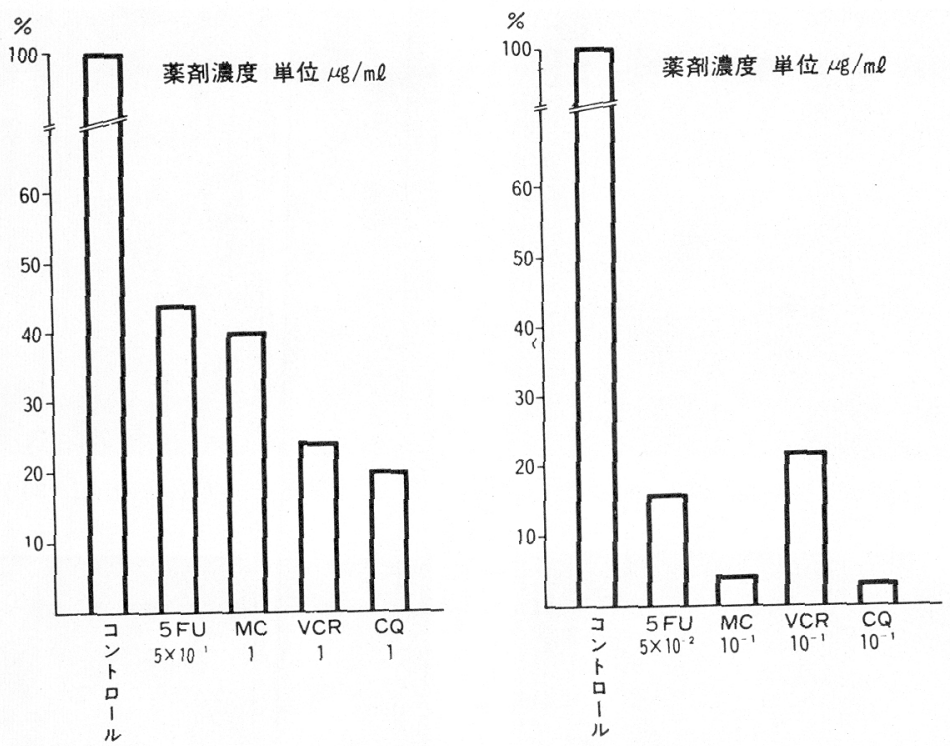

図 2

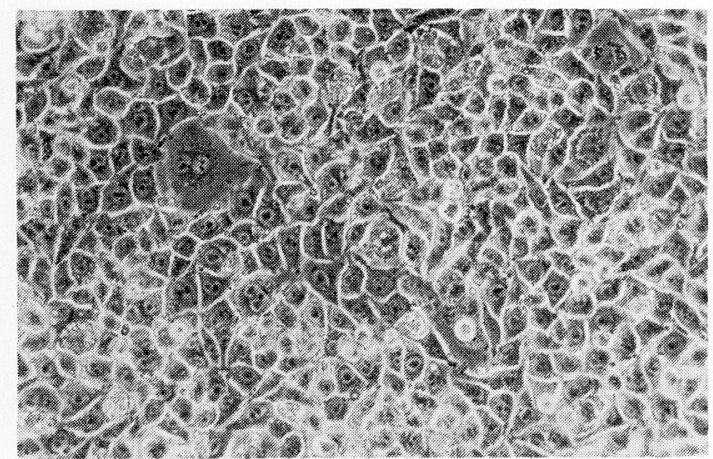

写真 1 無処置コントロール $(\times 200)$

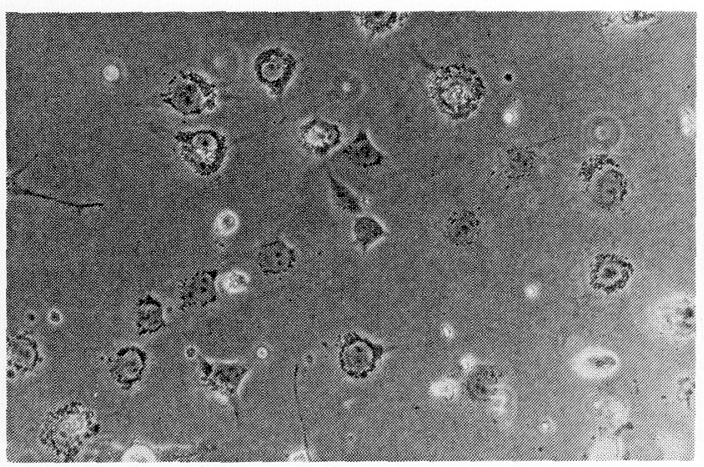

写真 $35 \mathrm{FU}, 5 \times 10^{-2} \mu \mathrm{g} / \mathrm{ml} \quad 24$ 時間接触 ( $\left.\times 200\right)$

乙約 $40 \%$ 程度，疎となり，小突起や顆粒細胞など $5 \mathrm{FU}$ と同様の所見を呈した (写真 4 ).

MC 24 時間接触は, 細胞密度約 10\% 弱と極度に疎 と

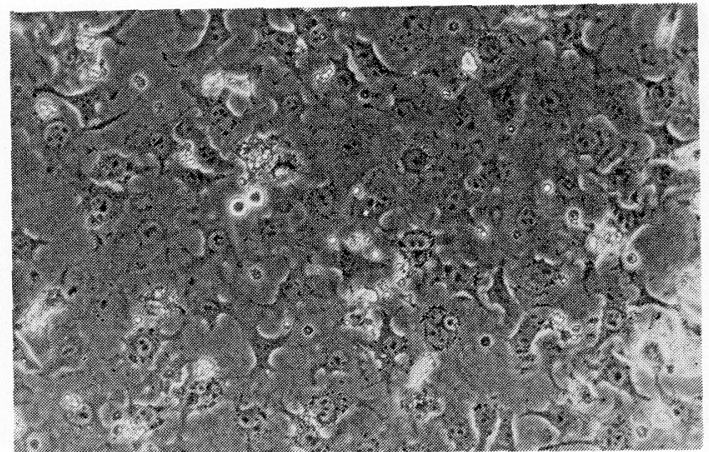

写真 $25 \mathrm{FU}, 5 \times 10^{-1} \mu \mathrm{g} / \mathrm{m} l \quad 30$ 分接触 $(\times 200)$

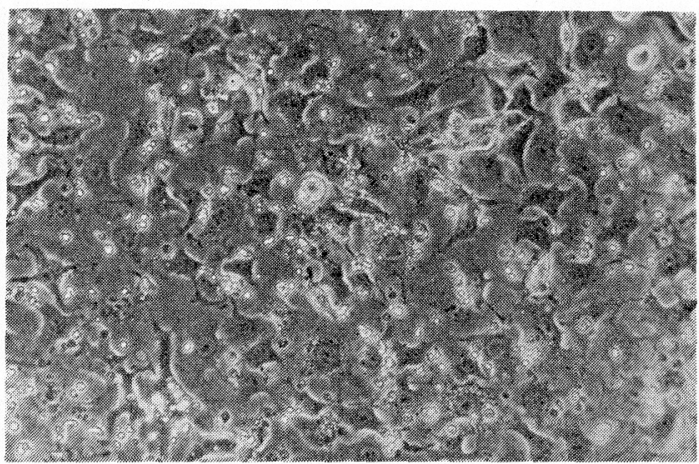

写真 $4 \mathrm{MC}, 1 \mu \mathrm{g} / \mathrm{m} l \quad 30$ 分接触 $(\times 200)$

なり，大突起細胞の出現や核の扁平化をきたし，大多数 の細胞化顆精を認めた (写真 5 ).

VCR 30 分接触では, $5 \mathrm{FU}, \mathrm{MC}$ 接触群とほほ同様の所 


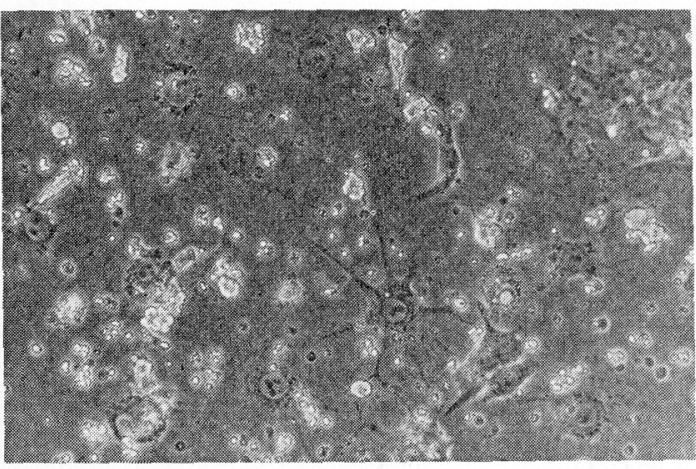

写真 $5 \mathrm{MC}, 10^{-1} \mu \mathrm{g} / \mathrm{m} l \quad 24$ 時間接触 $(\times 200)$

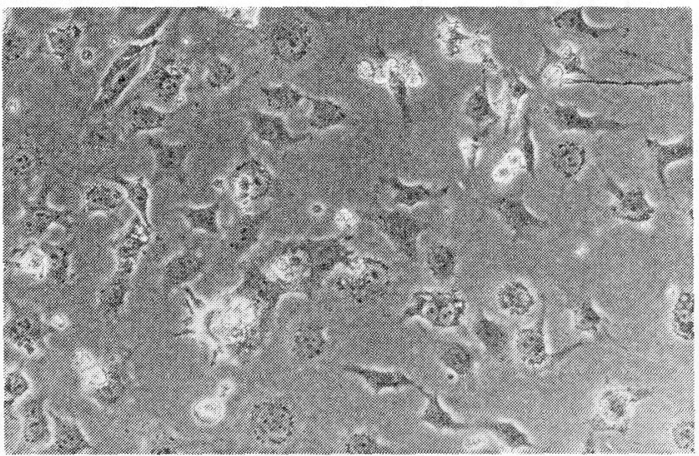

写真 7 VCR, $10^{-1} \mu \mathrm{g} / \mathrm{m} l \quad 24$ 時間接触 $(\times 200)$

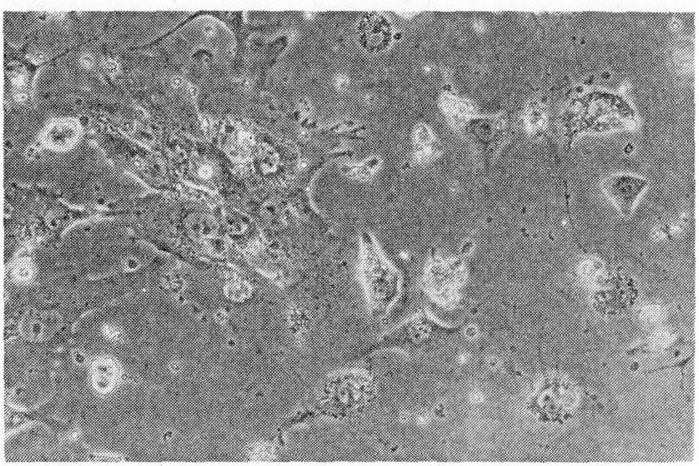

写真 $9 \mathrm{CQ}, 10^{-1} \mu \mathrm{g} / \mathrm{m} l \quad 24$ 時間接触 (×200)

見を示し，細胞密度も約 $40 \%$ 弱程度踈となった（写真 $6)$.

VCR 24 時閒接触では, 5FU, MC 接触群に比し突起在 有する細胞が少なくなり，細胞密度も約 $20 \%$ 程 度，疎 となった（写真 7 ).

CQ 30 分接触では，他剤に比し細胞密度が約 10\% 弱 と著しく䟱となり，大小突起と細胞質内顆粒も多数認め られた (写真 8 ).

CQ 24 時間接触では，30 分接触群よりも細胞密度が

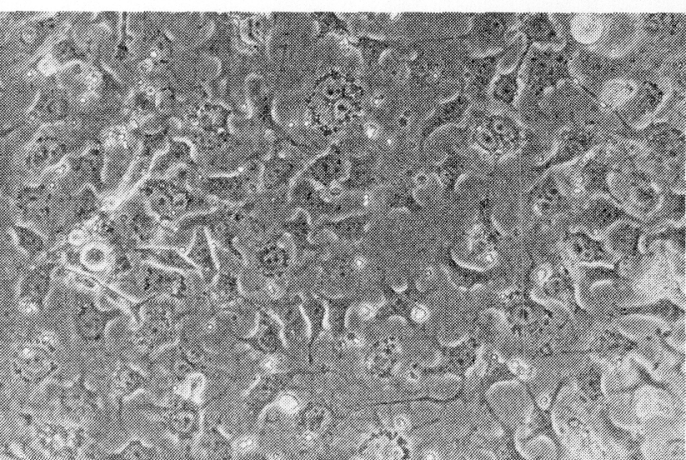

写真 $6 \mathrm{VCR}, 1 \mu \mathrm{g} / \mathrm{m} l \quad 30$ 分接触 $(\times 200)$

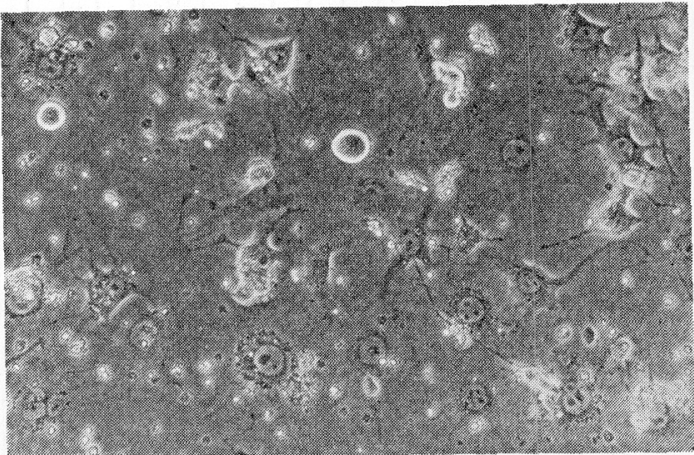

写真 $8 \mathrm{CQ}, 1 \mu \mathrm{g} / \mathrm{ml} 30$ 分接触 $(\times 200)$

\begin{tabular}{l|c|c|c|c}
\hline & $5 \mathrm{FU}$ & $\mathrm{MC}$ & $\mathrm{VCR}$ & $\mathrm{CQ}$ \\
\hline 30 分接触群 & 38 & 41 & 36 & 9 \\
\hline 24 時䦎接触群 & 8 & 8 & 19 & 6 \\
\hline
\end{tabular}

図 3 位相差顕微鏡下での無処置コントロールに対する 細胞密度 $(\%)$

さらに疎となり，大小突起を有する細胞も一層多く観察 され，同時に細胞質と核の腫大，扩よび細胞質融解が著 明となった (写真 9$)$.

以上要約すると殺細胞効果の所見としては，細胞密度 が疎となり (図 3 ), 細胞質内顆粒と大小突起の出現, 核の扁平化，核㧍よび細胞質腫大などが観察された。

2) Pap. 染色所見

無处置コントロール群では，細胞が敷石状に密に配列 し，細胞質は強塩基性，細胞膜は明膫，核は円形〜楕円 形でクロマチンに濃染し，核膜も明䐲で，核小体洨数個 観察された (写真 10).

5FU 30 分接触では, 細胞質注弱塩基性で, 軽度腫大 し，一部に小空胞孛認め，細胞膜㳉やや不明膫となっ た。核は多少腫大し, クロマチンは顆粒状, 核膜は薄い が明瞭で，核小体は腫大傾向を示した（写真 11). 


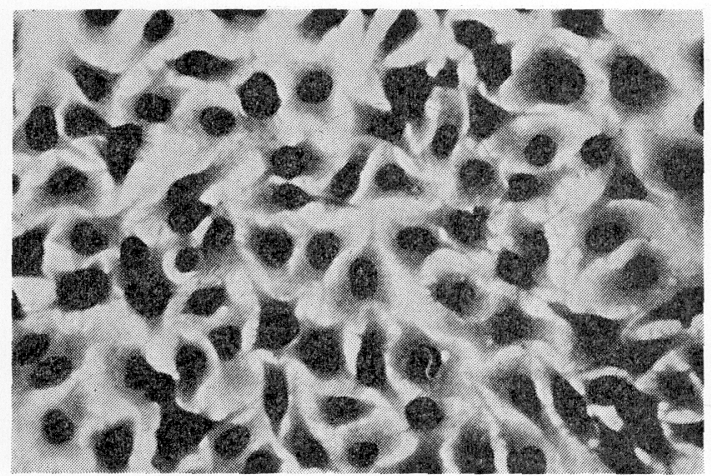

写真 10 無処置コントロール (Pap. 染色, × 400)

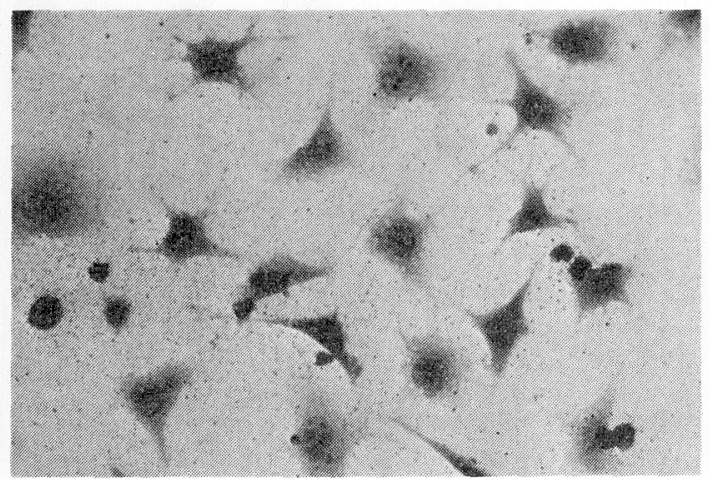

写真 $125 \mathrm{FU}, 5 \times 10^{-2} \mu \mathrm{g} / \mathrm{m} l 24$ 時間接触 (Pap. 染色, $\times 400$ )

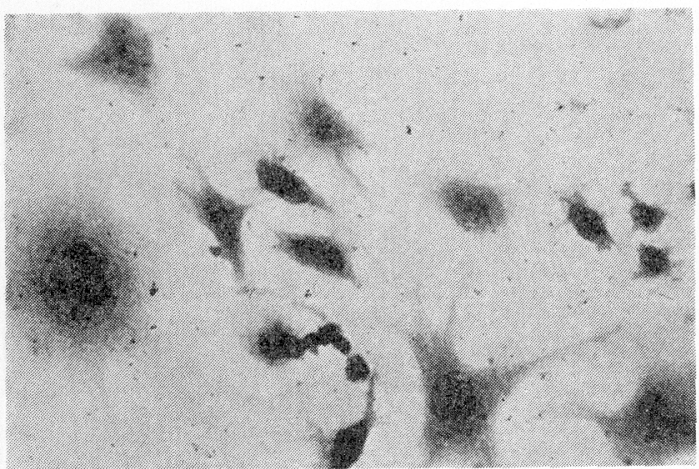

写真 $14 \mathrm{MC}, 10^{-1} \mu \mathrm{g} / \mathrm{ml}, 24$ 時閒接触（Pap. 染色， $\times 400)$

5FU 24 時間接触では, 小突起細胞の出現を認め, 細 胞質内に小空胞を有する細胞が多く出現した。核は中等 度腫大し, クロマチンは粗網状となり, 一部空胞を有 し，核小体は不明瞭となった（写真 12).

MC 30 分接触では, 細胞質の一部に小空胞索認め, 核は軽度腫大し, クロマチンは対照群と同様, 細網状で

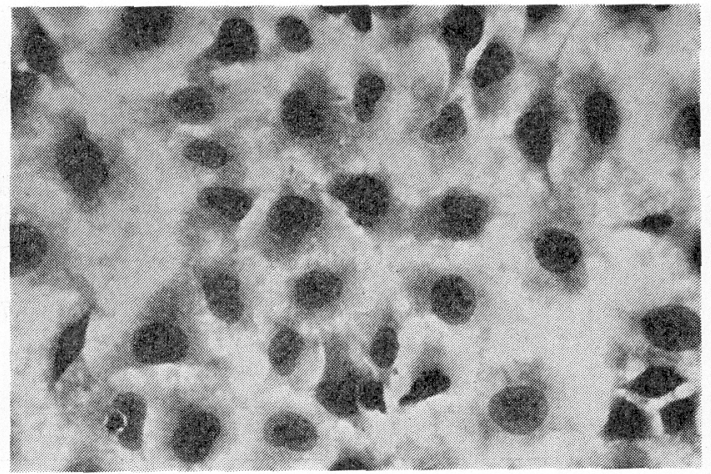

写真 $115 \mathrm{FU}, 5 \times 10^{-1} \mu \mathrm{g} / \mathrm{m} l 30$ 分接触（Pap. 染色， $\times 400$ )

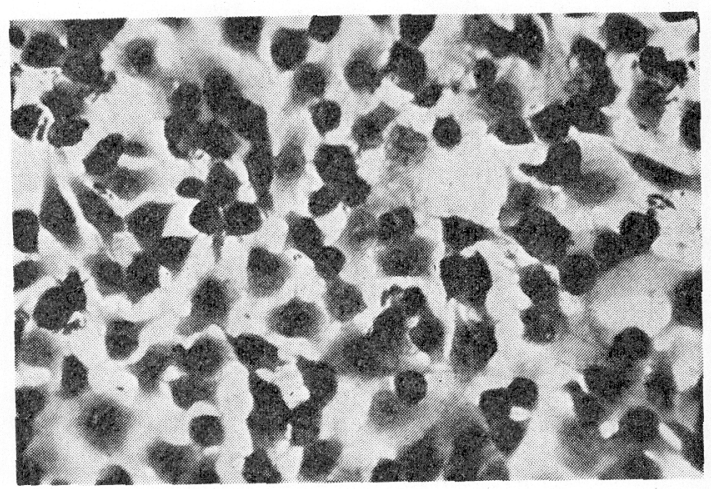

写真 $13 \mathrm{MC}, 1 \mu \mathrm{g} / \mathrm{m} l \quad 30$ 分接触 (Pap. 染色, $\times 400)$

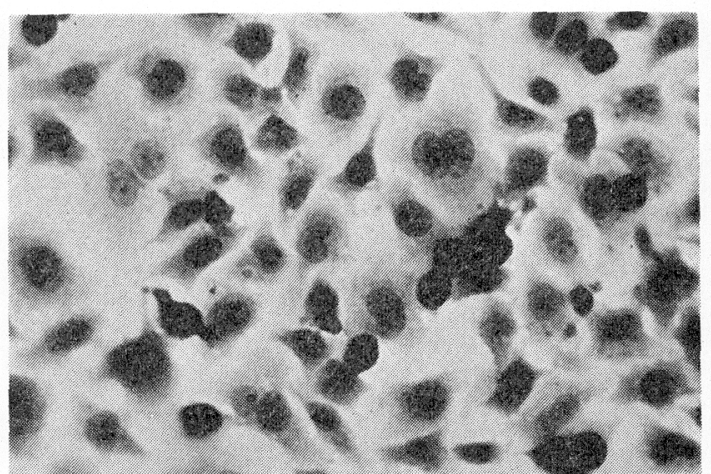

写真 $15 \mathrm{VCR}, 1 \mu \mathrm{g} / \mathrm{m} l 30$ 分接触 (Pap. 染色, $\times 400$ )

椟膜はよく保たれ，核小体は軽度腫大傾向を示した（写 真 13$)$.

MC 24 時間接触では, 細胞質, 核ともに著しく腫大 し，小空胞が多数出現，核小体の腫大も著明であった (写真 14).

VCR 30 分接触では, 細胞質が中等度腫大し, 一部レ 一ス状を示し, 空胞も少数出現した。核は軽度腫大し, 


\begin{tabular}{|c|c|c|c|c|c|c|}
\hline & $\begin{array}{l}\text { 無、䞘 置 } \\
\text { コンロートール }\end{array}$ & $5 \mathrm{FU}$ & $\mathrm{MC}$ & VCR & $\mathrm{CQ}$ \\
\hline $\begin{array}{l}\text { 細 } \\
\text { 胞 } \\
\text { 質 }\end{array}$ & 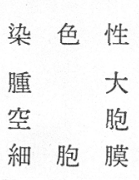 & \begin{tabular}{c} 
強 塩 基 性 \\
\multicolumn{3}{c}{$(-)$} \\
(-) \\
明 \\
\end{tabular} & $\begin{array}{c}\text { 弱塩 基 性 } \\
(+) \\
(+) \text { 小空胞 } \\
\text { や不明瞭 }\end{array}$ & $\begin{array}{c}\text { 弱 塩 基 性 } \\
\text { (土) } \\
(+) \text { 小空胞 } \\
\text { や不明瞭 }\end{array}$ & $\begin{array}{c}\text { 榒塩 基 性 } \\
( \pm \text { 部 } \\
( \pm) \\
(+) \text { 小空胞 } \\
\text { やや不明瞭 }\end{array}$ & $\begin{array}{c}\text { 低 下 } \\
(H) \\
\text { (十)大小空胞 } \\
\text { 不明膫 融解 }\end{array}$ \\
\hline 核 & $\begin{array}{lr}\text { クロマチン } \\
\text { 腫 } \\
\text { 大 }(\mu) \\
\text { 空 } \\
\text { 核 } \\
\text { r 胞 } \\
\end{array}$ & $\begin{array}{c}\text { 細 網 状 } \\
(-) 38.7 \\
(-) \\
\text { 明 瞭 }\end{array}$ & $\begin{array}{c}\text { 顆 粒 状 } \\
(+) 60.7 \\
(-) \\
\text { 明 瞭 }\end{array}$ & $\begin{array}{c}\text { 細 網 状 } \\
( \pm) \quad 43.2 \\
(-) \\
\text { 明 瞭 }\end{array}$ & $\begin{array}{c}\text { 顆 粒 状 } \\
(+) 49.1 \\
(-) \\
\text { 明 瞭 }\end{array}$ & $\begin{array}{c}\text { 粗 顆 粒 状 } \\
(\text { 井) } 80.3 \\
(+) \\
\text { やや不明瞭 }\end{array}$ \\
\hline & 体畽大 & $(-)$ & $(+)$ & $( \pm)$ & $( \pm)$ & $(t)$ \\
\hline
\end{tabular}

図 430 分薬剤接触群の Pap. 染色所見

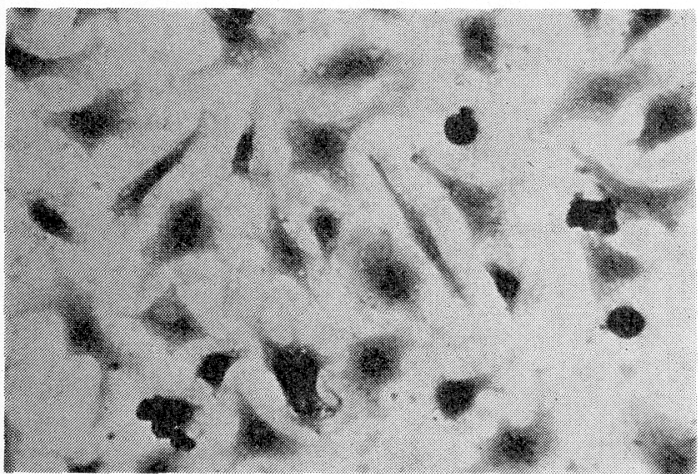

写真 $16 \mathrm{VCR}, 10^{-1} \mu \mathrm{g} / \mathrm{m} l 24$ 時閒接触 (Pap. 染色, $\times 400$ )

クロマチンは顆粒状，榜膜，核小体に著しい変化を認め なかった(写真 15).

VCR 24 時間接触では, 細胞質の染色性が低下し，小 空胞が多数出現，細胞膜は不明膫となった，核は軽度腫 大するとともに一部に凝集, 融解像や核内空胞も認めら れた (写真 16).

CQ 30 分接触では, 細胞質が著明に腫大するとともに 大小突起の出現を認めた。模は粗顆粒状を呈し，核なら びに核小体腫大も著明であった（写真 17 ).

CQ 24 時閒接触では, 細胞質が腫大かつ融解するとと もに，小空胞の出現や突起状変化が観察された。核は粗 網状に変化し，核破砕像も認められた（写真 18）.

以上 PAP. 染色所見を要約寸ると位相差所見と同様, 各薬剂間で差異は認められなかった。しかし 30 分接触 群で $5 \mathrm{FU}, \mathrm{CQ}$ が細胞質と核および核小体の腫大を認 め, 24 時間接触群で細胞質が突起状を呈し, 空胞化や腫 大さらに融解像を認めるとともに核は腫大かつ粗網状を 示し，核膜の不明瞭化や核小体の腫大などが各薬剤とも に観察された（図 4,5).

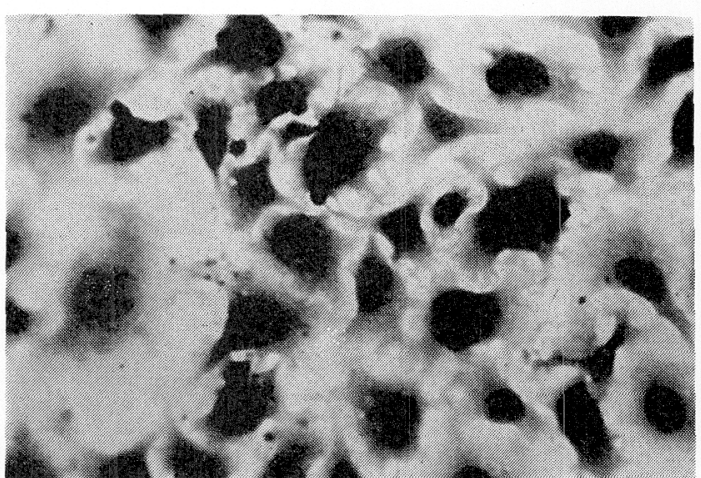

写真 $17 \mathrm{CQ}, 1 \mu \mathrm{g} / \mathrm{ml} 30$ 分接触 (Pap. 染色, $\times 400$ )

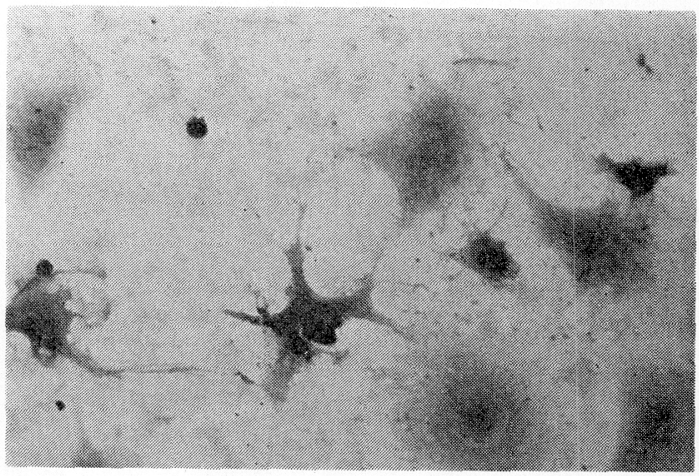

写真 $18 \mathrm{CQ}, 10^{-1} \mu \mathrm{g} / \mathrm{ml} 24$ 時間接触 (Pap. 染色, $\times 400$ )

3) 薬剂接触後の椟腫大

核長径は, 各薬剤接触後, 対照群に比し, いずれも増 大した. 一なわち 30 分接触群の平均核長径は対照群の $38.7 \mu$ に比し CQ $80.3 \mu, 5$ FU $60.7 \mu$, VCR $49.1 \mu$, $\mathrm{MC} 43.2 \mu$ の順に増大した。 また 24 時閒接触群では CQ $85.0 \mu$, MC $74.6 \mu, 5 \mathrm{FU} 69.1 \mu$, VCR $58.3 \mu$ の数 值を示した。 さらに各薬剤とも，当然のことながら 24 時間接触群が 30 分接触群に比し腫大率が大きく, と 


\begin{tabular}{|c|c|c|c|c|c|c|}
\hline & $\begin{array}{l}\text { 無ン処 置 } \\
\text { コンロートール }\end{array}$ & $5 \mathrm{FU}$ & $\mathrm{MC}$ & VCR & $\mathrm{CQ}$ \\
\hline $\begin{array}{l}\text { 細 } \\
\text { 胞 } \\
\text { 質 }\end{array}$ & $\begin{array}{lll}\text { 染 } & \text { 色 } & \text { 性 } \\
\text { 腫 } & & \text { 大 } \\
\text { 空 } & & \text { 胞 } \\
\text { 細 } & \text { 胞 } & \text { 膜 }\end{array}$ & $\begin{array}{c}\text { 強 塩 基 性 } \\
(-) \\
(-) \\
\text { 明 瞭 }\end{array}$ & $\begin{array}{l}\text { 低 下 } \\
(+) \text { 突起状 } \\
(-) \text { 小空胞 } \\
\text { 不明膫 融解 }\end{array}$ & $\begin{array}{l}\text { 低 下 } \\
(+) \text { 突起状 } \\
(+) \text { 小空胞 } \\
\text { 不明膫 融解 }\end{array}$ & $\begin{array}{l}\text { 低 下 } \\
(+) \text { 突起状 } \\
(+) \text { 小空胞 } \\
\text { 不明瞭 融解 }\end{array}$ & $\begin{array}{l}\text { 低 下 } \\
(+) \text { 突起状 } \\
(+) \text { 大小空胞 } \\
\text { 不明瞭 融解 }\end{array}$ \\
\hline 核 & $\begin{array}{lr}\text { クロマチン } \\
\text { 腫 } & \text { 大 }(\mu) \\
\text { 空 } & \text { 胞 } \\
\text { 核 } & \text { 膜 }\end{array}$ & $\begin{array}{c}\text { 細 網 状 } \\
(-) 38.7 \\
(-) \\
\text { 明 瞭 }\end{array}$ & $\begin{array}{c}\text { 粗 網 状 } \\
(+) 69.1 \\
(+) \\
\text { 不明瞭 }\end{array}$ & $\begin{array}{c}\text { 粗 網 状 } \\
(H) 74.6 \\
(+) \\
\text { 不明瞭 }\end{array}$ & $\begin{array}{c}\text { 粗 網 状 } \\
(H) 58.3 \\
(+) \\
\text { 不明瞭 }\end{array}$ & $\begin{array}{c}\text { 粗 網 状 } \\
(\text { 册) } 85.0 \\
(+) \\
\text { 不明瞭 }\end{array}$ \\
\hline & 小体 腫 大 & $(-)$ & (+)不明瞭化 & (+)不明瞭化 & (t)不明瞭化 & （\#） 不明瞭 \\
\hline
\end{tabular}

図 524 時間薬剤接触群の Pap. 染色所見

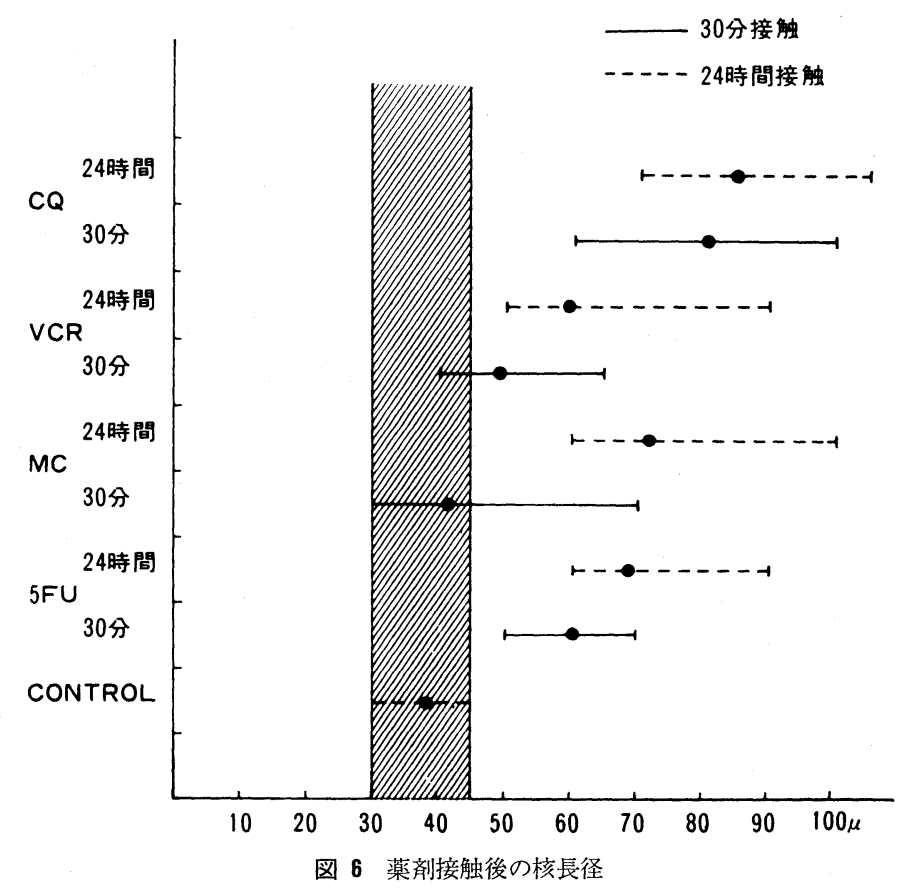

くに CQ は他剤に比し著しく増大し, 対照群の約 2 倍の 高値を示した．以上のことは各薬剤の生残率—CQ, MC $10 \%$ 以下, $5 \mathrm{FU} 20 \%$ 弱, VCR $20 \%$ 強一の順位と 相関を有することになり核腫大と生残率〜細胞死の関連 性が強く示唆された（図6).

4） ICP による DNA ヒストグラムの解析

$5 \mathrm{FU}$ では, LI が対照群の 20.0 に比し 35.5 と上昇し たことから $\mathrm{S}$ 期における蓄積が考えられた. VCR では， $\mathrm{MI}$ が対照群の 3.21 に比し 8.65 と上昇したことから late $\mathrm{G}_{1} \sim \mathrm{S}$ 期蓄積と $\mathrm{G}_{2}+\mathrm{M}$ の増加が示唆され, $\mathrm{MC}$ で も同様, 軽度 $\mathrm{G}_{2}+\mathrm{M}$ の増加が考えられた. $\mathrm{CQ}$ の解析 では, $\mathrm{LI}=0, \mathrm{MI}=0$ を示したことから細胞回転の停止 が考えられ，2n 以下の deblis と $\mathrm{S}$ 期蓄積，および多数 の高倍体細胞の出現が観察された（図 7〜10).

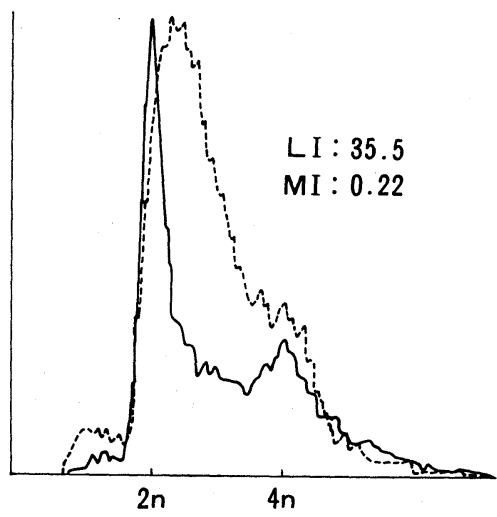

図 $75 \mathrm{FU} 5 \times 10^{-1} \mu \mathrm{g} / \mathrm{m} l \quad 30$ 分接触 


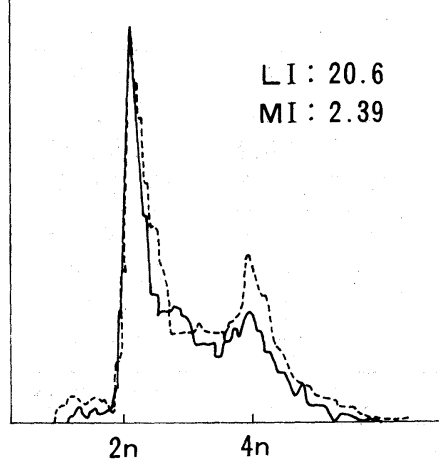

図 $8 \mathrm{MMC} 1 \mu \mathrm{g} / \mathrm{m} l \quad 30$ 分接触

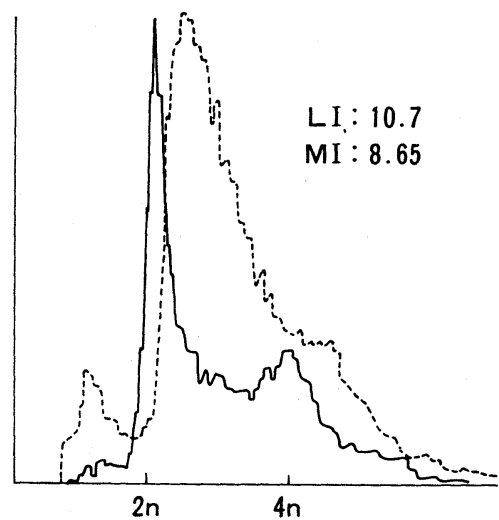

図 $9 \mathrm{VCR} 1 \mu \mathrm{g} / \mathrm{m} l \quad 30$ 分接触

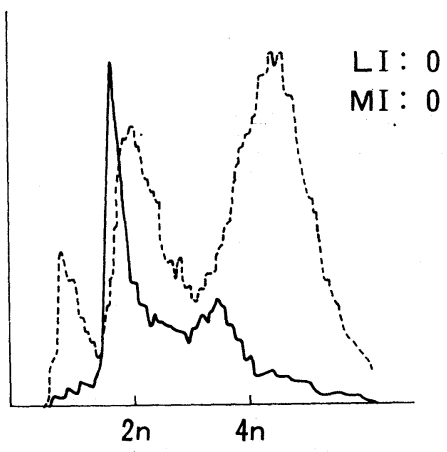

図 $10 \mathrm{CQ} 1 \mu \mathrm{g} / \mathrm{m} l \quad 30$ 分接触

\section{IV． 総括ならびに考案}

In vitro 制癌剤感受性試験は種々行われているが，い まだ確立されたとはいいがたい，現在，各種脱水素酵素 を指標とした試験 ${ }^{1,7,11)}$ ，isotope を用いた方法 ${ }^{5)}$ ，組織 培養を利用した試験 ${ }^{16)}$ と，種々試みられているが，われ われは薬剤接触後の細胞形態変化に注目し，とくに位相
差顕微鏡，Pap. 染色所見，核腫大率および DNA ヒス トグラムを中心に検討を試みた.

位相差顕微鏡を用いた観察では，対照群 72 時間 培 養 により円形〜棈円形の腫瘍細胞が密に増殖した。一方, 薬剂接触群では, (1) 細胞質内顆粒, (2) 大小突起細胞の出 現が特徵的であり，その他，細胞質ならびに核腫大，細 胞質および核融解といった所見が観察された。しかしな がら,これら形態的変化は各薬剤間での特徴的変化とし ては認められなかった。

また殺細胞効果の認められた CQ 群では，ほとんど生 着能が失われて浮遊細胞となった. すなわち生着能を失 った細胞は薬剤接触により細胞活性が低下し，高度の細 胞障害を受けていることが観察された。しかしながら非 生着細胞をすべて死細胞と認定するには問題があり，細 胞周期内に不可逆性变化を受け死減する interphase death を示すのか，または薬剤の作用を受けた後の周期 に死減する reproductive death を示すのか不明であ り,さらには逆に修復細胞として活性を獲得するのか本 実験では結論を見い出すことができなかった.

Pap. 染色所見では，位相差と同様，薬剂間で特異な 形態的変化は観察されなかったが，薬剤により細胞質， 核，および核小体に種々の変化が認められた。すなわち 細胞質では, 染色性の低下, 腫大, 空胞出現, 細胞膜の 不明瞭化を認め, 核ではクロマチンの粗網状変化や腫 大, 空胞が出現し, 核小体では腫大, 不明瞭化が特徴的で あった．以上の所見は安田ら ${ }^{19)} の$ in vivoにおける制癌 剂の腫瘍細胞の形態変化とほぼ同様であり, in vitro に おいてこの形態的変化は薬剤濃度や作用時間にある程度 相関を有することが判明した。

また西浦 ${ }^{12)}$ は, Hela 細胞を用い，放射線照射による形 態的変化を観察し，とくに核腫大と細胞死の関係につい て検討, 放射線照射後, 核径が 1.5 倍を凌駕した場 合 は，もはや無限增殖能をもち得ないとし，やがて死に至 る細胞といい得ると述べている，本実験の成績でも生残 率の著明な減少を示した $\mathrm{CQ}$ では, 30 分， 24 時閒とも に他剤に比し 2 倍以上の核腫大を示しており，死細胞の 増加と核腫大との間には，きわめて密な相関を有すると 考えられ, in vitro 制癌剂感受性試験のパラメーターに なり得ることが強く示唆された.

DNA ヒストグラムの検討は，制癌剤の細胞回転に与 える影響を観察することにより薬剤の腫瘍細胞に対する 作用機序を知ることができ，制癌剤感受性試験上きわめ て重要である.

$5 \mathrm{FU}$ の実験成績では, 細胞回転上 $\mathrm{G}_{1}, \mathrm{G}_{2}, \mathrm{M}$ 期に細 胞にあまり影響を与えず, LI が上昇したことから S 期に 
入って DNA 合成阻害をきたしたことが推察され， $\mathrm{S}$ 期 蓄積を示したと考えられた，以上のことは，諸家の報告 による phase specific ${ }^{2)}$, しかも S-phase specific ${ }^{7)}$ 薬刘といわれていることとも一致する。

$\mathrm{MC}$ の解析では, 軽度 $\mathrm{G}_{2}+\mathrm{M}$ の増加を認めたにすぎ なかったが，従来の報告4,14)によれば本剤は $\mathrm{G}_{2}$ 期に感 受性を示すとされている.

VCR では, 接触後, 対照群の $\mathrm{MI}=3.21$ に比し 8.65 と上昇したことから分裂阻止作用が推察された。本剤は phase specific ${ }^{2)}$ で, かつ metaphase arrest 作用を有する ことが多数報告されており，これまた本実験結果と同様 の成績を示した.

$\mathrm{CQ}$ では, $\mathrm{LI}=0, \mathrm{MI}=0$ を示したことから $\mathrm{Krishan}^{8)}$ らの細胞回転の進行停止と考えられ，その作用は短時間 速効性を有すると思われた。

\section{V. 結論}

ヒト卵巣腫瘍由来の細胞株 (JOHYL-1)を用、制癌剂 感受性試験を行い薬剤接触前後の細胞形態を観察, 以下 の結果を得た。

1）位相差顕微鏡では, 細胞質内顆粒を認め, 細胞質 ならびに核腫大を伴った大小突起細胞が観察された.

2） Pap. 染色では細胞質の染色性が低下し，腫大， 空胞化ならびに細胞膜の不明膫化を呈し，核は腫大し， 空胞の出現やクロマチンの粗網状変化を示すとともに核 小体の腫大が観察された.

3) Tripan blue による dye exclusion method と核 長径測定による核腫大の検討では, 核腫大と死細胞増加 の間に，きわめて密接な相関を有することが判明した。

4）ICP による核 DNA ヒストグラムの解析では, 5 FU, MC, VCR ともに cycle specificity を示し, 殺細 胞効果のもっとも高度な $\mathrm{CQ}$ では細胞回転の停止を認め た.

以上の成績より核腫大と細胞死の間には密接な関連が 認められ, in vitro 制癌剤感受性試験のパラメーターと なりらることが強く示唆された.

\section{Summary}

Using a cell line (JOHYL-1) of human ovarian anaplastic disgerminoma, a sensitivity testing of anticancer drugs was studied. After exposure of anticancer agents, a cytomorphological study was made to obtain results as follows.
1) A phase-contrast microscopic examination revealed that

(1) large and small prickle cells with swelling of the cytoplasm and the nucleus and (2) cytoplasmic granules.

2) Papanicolaou staining revealed that (1) a decline in staining, swelling, and vacuoles of the cytoplasm, and obscure cell membrane, (2) a reticular change in chromatin, swelling and vacuoles of the nucleus and (3) swollen and obscure patterns of the nucleori.

3) By the measurement of the major axis of the nucleus suggested that the number of the swollen nucleus corelated to the number of dead cells each other.

4) By analysis of nuclear DNA histogram by Impuls cytophotometer, $5 \mathrm{FU}, \mathrm{MC}$ and VCR showed a cycle specificity as reported previously. $\mathrm{CQ}$ rated as the foremost in the cytocidal effect showed stoppage of the cell cycle.

Therefore, we concluded that it was possible to state that nuclear diameter can be used as the parameters for the sensitivity testing of anticanceragents assess the relationship between swelling of the nucleus and death of the cell can be data of nuclear decline the as the parameters for the sensitivity testing of anticancer drugs.

\section{文献}

1) Black, M.M. and Speer, F.D. : In vitro and clinical effects of urethane plus triethylene-melanimine on human breast cancer, Surg. Gynec. Obst., 102 : 420 426, 1955.

2) Bruce, W.R., Meeker, B.E. and Valeriote, F.A.: Comparison of the sensitivity of normal hematopoietic and transplanted lymphoma colony-forming cells to chemotherapeutic agents administered in vivo, J.N.C.I., $37: 233 \sim 245,1966$.

3) Cutts, J.H. : The effect of vinca leukoblastine on dividing cells in vivo, Cancer Res., $21: 168 \sim 172$, 1961.

4) Djordjevic, B. and Kim, J.H. : Different lethal effect of mitomycin $\mathrm{C}$ and actinomycin $\mathrm{D}$ during the division cycle of Hela cells, J. cell Biol., $38: 477 \sim 482$, 1968.

5）貴島幸彦：核酸と蛋白の生合成に対寸る抑制効果を指標 とする制癌剤感受性試験の基礎的研究, Chemotherapy, $14: 621 \sim 627,1966$. 
6）小林仁道：培養した腫瘍細胞に及ぼすマイトマイシンの 影響, 遺伝学雑誌, $34: 344 \sim 350,1959$.

7）近藤達平 ・他 : 制癌剤適応判定法について, 癌の臨床, $10: 17 \sim 21,1964$.

8) Krishan, A. and Frei, III.E. : Effect of adriamycin on the cell cycle traverse and kinetics of cultured human lymphoblasts, Cancer Res., $36: 143 \sim 150$, 1976.

9) Lapis, K. and Bernhard, W. : The effect of mitomycin $\mathrm{C}$ on the nucleolar fine structure of $\mathrm{KB}$ cells in cell culture, Cancer Res., $25: 628 \sim 645,1965$.

10）本山悌一・他：制癌剤の効果判定に関寸る基礎的研究, 日臨細胞誌, $21: 15 \sim 25,1982$.

11）西岡久寿弥・他：人の悪性腫瘍の制澏性ウイルス及び化 学療法剤に対する感受性試験のこ > み, 日本臨床, 15 : 23 34, 1937.

12）西浦天宣：放射線照射による Hela 細胞の形態学的変化 に関する研究, 特に核腫大現象からみた細胞死の判定の ために，日臨細胞誌，19:524 531，1980.

13）野獄幸雄 : 細胞水準における放射線・制癌剂効果判定の 基準私見，産婦人科の世界，13：1879 1896，1961.
14) Ohara, H. and Terasima, T. : Lethal effect of mitomycin $\mathrm{C}$ on cultured mammalian cells, GANN, $63: 317 \sim 327,1972$.

15) Palmer, C.G., Iivengood, D., Warren, A.K., Simpson, P.J. and Johnson, I.S. : The action of vincaleukoblastine on mitosis in vitro, Exp. Cell. Res., $20: 198 \sim 201,1960$.

16）下山正徳, 木村禧代二 : 抗癌剤の殺細胞作用の定量法, Chemotherapy, $20: 787 \sim 794,1972$.

17) Skipper, H.E., Schabel, Jr., F.M., Mellet, L.B., Montgomery, J.A., Wilkoff, L.J., Lloyd, H.H. and Brockman, R.W.: Implications of biochemical, cytokinetic, pharmacologic, and toxicologic relationships in the design of optimal therapeutic schedules, Cancer Chemother. Rept's., $54: 431 \sim$ 450, 1970.

18）安田 允・他：ヒト卵巣胚細胞由来の性状と HCG 産 生能, 日本癌学会総会記事, $40: 182,1981$.

19）安田 允・他 : 卵巣癌腹水細胞の抗癌剤による形態的変 化, 日臨細胞誌, $20: 268 \sim 274,1981$. 